\title{
REAKSI PASAR MODAL TERHADAP PERISTIWA BENCANA BANJIR DI JAKARTA, BOGOR, DEPOK, TANGERANG, DAN BEKASI (JABODETABEK) PADA BULAN JANUARI 2020
}

\author{
Karin Putri Kurnia Sari \\ Umrotul Khasanah
}

Universitas Islam Negeri Maulana Malik Ibrahim Malang

Karinputriks@gmail.com

\begin{abstract}
The flood disaster that struck several points in Jabodetabek on January 1, 2020, caused a loss. According to historical BMKG data, the flood is the highest in the last 24 years. The purpose of this study is to find and analyze empirical evidence of the presence or absence of Abnormal Returns, Trading Volume Activity, and Security Return Variability in January 2020. This research uses the results of a descriptive quantitative approach. Data is collected by means of documentation. The sample used is companies incorporated in the Consumer Goods Industry sector, the Real Estate Property and Building Construction sector, the Utility Infrastructure and Transportation sector, and the Trade in Services and Investment sector. Based on the results of the study seen from the IBK, IUT, and PJI abnormal returns did not provide significant changes before and after the event, changes only when the event with sig. 0,000. In the CRP sector the impact of the changes was significant at sig 0,000 and after the event at sig 0.018. The volume of activity in the CRP, IUT, and PJI sectors did not significantly change before and after the event, only at the moment with sig. of 0,000 . Security return variability in IBK and IUT sector groups did not provide significant changes. The PJI sector had the prior impact with sig. 0.025 and when 0.000 , the CRP sector changes only when the event value sig. of 0,000.
\end{abstract}

Keyword : Abnormal Return, Trading Volume Activity, Security Return Variability 


\section{PENDAHULUAN}

Pasar modal Indonesia sekarang sudah berkembang menjadi salah satu sumber pendanaan jangka panjang bagi dunia usaha dan pemerintah. Berbagai program seperti pembangunan infrastruktur pun turut didorong menggunakan pendanaan dari pasar modal. Hal ini sesuai dengan tujuan dari pasar modal sendiri yaitu menunjang pelaksanaan pembangunan nasional yang memiliki peran strategis sebagai salah satu sumber pendanaan dunia usaha (Meidawati dan Harimawan, 2004). Semakin penting peran pasar modal bagi sebuah negara maka semakin sensitif pasar modal tersebut terhadap berbagai peristiwa yang memiliki kandungan informasi (Suryawijaya dan Setyawan, 1998). Sehingga informasi dapat mempengaruhi naik turunya harga saham (Azhar, dkk, 2013). Untuk investor, informasi sebagai salah satu faktor penting dalam mengambil keputusan investasi.

Event study (studi peristiwa) merupakan studi yang mempelajari reaksi pasar terhadap suatu peristiwa (event) yang informasinya dipublikasikan sebagai suatu pengumuman. Event study dapat digunakan untuk menguji kandungan informasi dari suatu pengumuman dan dapat juga digunakan untuk menguji efisiensi pasar bentuk setengah kuat menurut Jogiyanto (2013). Jogiyanto (2013) menyatakan bahwa pengujian kandungan informasi dimaksudkan untuk melihat reaksi dari suatu pengumuman. Jika pengumuman mengandung informasi, maka diharapkan pasar bereaksi pada waktu pengumuman tersebut diterima oleh pasar. Reaksi pasar yang ditunjukkan dengan adanya perubahan harga dari sekuritas bersangkutan. Reaksi ini dapat diukur dengan menggunakan return sebagai nilai perubahan harga atau dengan menggunakan abnormal return. Dari penjelasan mengenai event study yang diberikan oleh Jogiyanto (2013) dapat disimpulkan bahwa peristiwa bencana banjir yang terjadi di Jabodetabek pada bulan Januari 2020 merupakan bagian dari event study.

Bencana banjir yang melanda beberapa titik di Jabodetabek pada 1 Januari 2020, menimbulkan dampak kerugian. Badan Nasional Penanggulangan Bencana (BNPB) mencatat jumlah titik banjir yang melanda Jabodetabek dan Lebak, Banten mencapai 182 titik. Kepala Pusat Data Informasi dan hubungan Masyarakat BNPB Agus Wibowo (melalui kompas.com: 2020) menyampaikan bahwasannya jumlah titik banjir terbanyak tercatat di Kota Bekasi sebanyak 58 titik. Kemudian, jumlah titik terbanyak berikutnya berada di Jakarta Selatan, yaitu 39 titik, pada Kabupaten Bekasi sebanyak 27 titik banjir. Menurut data BNPB, jumlah wilayah yang terdampak banjir berjumlah 109 kecamatan dan 303 kelurahan yang tersebar di Jabodetabek dan Lebak, Banten.

Bappenas (melalui bisnis.com) mengasumsikan bahwa nilai kerusakan dan kerugian hampir mencapai Rp5,2 triliun. Angka tersebut belu $\mathrm{m}$ termasuk kerugian ekonomi yang dialami oleh sektor usaha dan asuransi yang diperkirakan senilai US\$400 juta, atau setara dengan Rp3,6 triliun selama 7-10 
hari terjadinya bencana banjir di wilayah Jabodetabek. Dari perhitungan kerusakan dan kerugian yang bersifat langsung atau direct impact, sebesar Rp5,2 triliun, sejumlah $\mathrm{Rp} 4,5$ triliun merupakan aset milik swasta/masyarakat, dan selebihnya Rp650 miliar merupakan kerusakan dan kerugian dari aset milik pemerintah/BUMN/BUMD. Menurut Kepala Riset dan Strategis Bahana Sekuritas Harry Su (melalui finance.detik.com: 2017), musibah banjir mempengaruhi kinerja operasional beberapa sektor emiten. Oleh karena itu banjir juga akan menjadi sentimen bagi pergerakan saham. Emiten di sektor infrastruktur dan pertambangan akan terkena imbas dari musibah banjir.

Menurut Andi Yuwono (2013) terdapat abnormal return positif pada saham yang bergerak di sektor consumer goods industry dan sub sektor retail di hari peristiwa bencana Banjir di DKI Jakarta tahun 2013. Menurut Christian Martha Fanni (2017) reaksi pasar modal terhadap peristiwa banjir Jakarta 2013 hanyalah sesaat dan tidak berkepanjangan. Diungkapkan pada penelitian Febby Wulandari dan Khairunnisa (2017) bahwa tidak terdapat perbedaan abnormal return dan trading volume activity pada saham perusahaan asuransi sebelum dan sesudah peristiwa bencana banjir baik pada tahun 2007 maupun 2013.

Penelitian ini akan mengidentifikasi hasil-hasil penelitian terdahulu yang belum konsisten terkait peristiwa bencana banjir terhadap abnormal return, trading volume activity, dan security return variability, yang ditunjukkan dengan adanya reaksi pasar positif maupun negatif. Reaksi positif pasar modal terhadap abnormal return ditunjukkan pada penelitian yang dilakukan oleh Rahayu (2007), dan Wardhani (2013). Penelitian yang dilakukan oleh Islami dan Sarwoko (2012) tentang reaksi pasar modal Indonesia terhadap pergantian Menteri Keuangan (event study saham yang terdaftar di BEI) menunjukkan bahwa tidak terdapat signifikansi security return variability, yang berarti bahwa pasar modal Indonesia tidak bereaksi atas peristiwa kemunduran Sri Mulyani dari jabatan Menteri Keuangan.

Pada penelitian ini perusahaan yang dipilih adalah perusahaan yang terdapat pada kelompok sektor industri barang konsumsi, sektor properti real estate dan kontruksi bangunan, sektor infrastruktur utilitas dan transportasi, dan sektor perdagangan jasa dan investasi di Bursa Efek Indonesia dikarenakan sektor-sektor tersebut menurut beberapa analisator dari berbagai sekuritas atau perusahaan efek merupakan sektor yang berpengaruh pada peristiwa bencana banjir di Jabodetabek pada Bulan Januari 2020. Berdasarkan latar balakang masalah tersebut penulis mengambil judul "Reaksi Pasar Modal Terhadap Peristiwa Bencana Banjir di Jakarta, Bogor, Depok, Tangrang, Bekasi (Jabodetabek) Pada Bulan Januari 2020".

Tujuan dari penelitian ini adalah untuk menemukan dan menganalisis bukti empiris ada tidaknya perbedaan yang signifikan pada Abnormal Return, Trading Volume Activity, dan Security Return Variability sebelum, saat, dan setelah terjadinya bencana banjir di 
Jabodetabek pada Bulan Januari 2020 .

\section{METODE PENELITIAN Jenis dan Pendekatan Penelitian}

Penelitian ini menggunakan metode penelitian kuantitatif, dikarenakan data utamanya berupa angka-angka yang analisisnya menggunakan statistik. Pendekatan penelitian dalam penelitian ini menggunakan pendekatan studi peristiwa (event study). Jogiyanto (2013 : 555) berpendapat bahwa studi peristiwa merupakan studi yang mempelajari reaksi pasar terhadap suatu peristiwa (event) yang informasinya dipublikasikan sebagai suatu pengumuman. Menurut Tandelilin (2010 : 566) Studi peristiwa dapat digunakan untuk menguji kandungan informasi dari suatu pengumuman terhadap harga sekuritas.

\section{Lokasi Penelitian}

Data penelitian ini diambil dari Galeri Investasi Bursa Efek Indonesia yang berlokasi di fakultas Ekonomi UIN Maliki Malang. Selain itu, penelitian ini mengambil data dari website resmi yang bersangkutan www.idx.com. Periode pengamatan dalam penelitian ini adalah selama periode 10 hari yaitu 23 Desember 2019 - 09 Januari 2020.

\section{Sampel Penelitian}

Pengambilan sampel dilakukan dengan menggunakan teknik purposive sampling yang mana teknik tersebut merupakan teknik yang dipilih oleh peneliti dengan menggunakan kriteria dalam memilih sampel. Menurut Sugiyono (2014 : 122) purposive sampling yaitu teknik pengambilan sampel dengan kriteria tertentu. Setelah dilakukan pengambilan sampel dengan menggunakan teknik purposive sampling maka jumlah emiten yang dijadikan sampel akhir dalam penelitian ini berjumlah 42 emiten. Kriteria sampel yang dipilih oleh peneliti yaitu: (1) Saham-saham yang tercatat di Bursa Efek Indonesia pada kelompok sektor industri barang konsumsi, sektor properti real estate dan konstruksi bangunan, sektor infrastruktur utilitas dan transportasi, dan sektor perdagangan jasa dan investasi. (2) Saham tercatat sebagai emiten di Bursa Efek Indonesia dan termasuk dalam kategori saham indeks IDX 80. (3) Saham-saham tersebut tercatat di Bursa Efek Indonesia pada periode terjadinya event yaitu pada Bulan Agustus 2019 - Januari 2020.

\section{Definisi Operasional Variabel \\ a. Abnormal Return}

Abnormal return sering digunakan sebagai evaluasi terhadap hasil yang dapat diberikan oleh suatu saham, dimana nilai yang diperoleh menunjukkan ekspektasi investor terhadap hasil aktual saham dengan hasil yang diharapkan dari saham tersebut pada waktu t. Menurut Jogiyanto (2013) Abnormal return adalah selisih antara return sesungguhnya yang terjadi dengan return ekspektasi. Secara matematis dirumuskan sebagai berikut:

$$
\mathrm{AR}_{\mathrm{it}}=\mathrm{R}_{\mathrm{it}}-\mathrm{R}_{\mathrm{mt}}
$$

Dimana:

$\mathrm{AR}_{\mathrm{it}}=$ abnormal return sekuritas $(\mathrm{i}$ ) pada periode ke- $\mathrm{t}$

$\mathrm{R}_{\mathrm{it}}=$ actual return sekuritas ( $\mathrm{i}$ ) pada periode ke- $\mathrm{t}$ 
$\mathrm{R}_{\mathrm{mt}}=$ return pasar pada periode ke- $\mathrm{t}$ Actual Return saham i pada hari t dapat dihitung

menggunakan rumus :

$$
\mathrm{R}_{\mathrm{i}, \mathrm{t}}=\frac{P i, t-P i, t-1}{P i, t-1}
$$

$\mathrm{P}_{\mathrm{i}, \mathrm{t}-\mathrm{l}}=$ harga saham $\mathrm{i}$ pada $\mathrm{t}-1$

Dalam penelitian ini, expected return dihitung dengan menggunakan Mean Adjusted Model, ini dianggap bahwa ekspektasi bernilai konstan yang sama dengan rata-rata $i$ realisasi sebelumnya selama periode estimasi. Rumusnya adalah sebagai berikut:

$$
\mathrm{E}\left(\mathrm{R}_{\mathrm{it}}\right)=\frac{\sum_{t=1}^{n} R i}{n}
$$

$\mathrm{ER}_{\mathrm{itn}}=$ return ekspektasi sekuritas ke I pada periode peristiwa ke $\mathrm{t}$

$\mathrm{Ri}, \mathrm{j}=$ return realisasi sekuritas ke $\mathrm{i}$ periode estimasi ke $\mathrm{j}$

$\mathrm{T}=$ lamanya periode estimasi

\section{b. Trading Volume Activity}

Aktivitas volume perdagangan merupakan suatu instrumen yang dapat digunakan untuk mengukur tingkat kegiatan jual beli saham di bursa saham. TVA juga dapat mencerminkan seberapa aktif dan likuid suatu saham diperdagangkan di pasar modal. Untuk melakukan perhitungan TVA dapat dilakukan dengan membandingkan jumlah saham yang diperdagangkan dalam suatu periode tertentu dengan keseluruhan jumlah saham beredar perusahaan tersebut dalam kurun waktu yang sama. Formulasinya sebagai berikut:

\section{c. Security Return Variability}

Menurut Husnan (1996) pengujian reaksi harga dan tingkat keuntungan dapat dilihat dari security return variability (SRV) dengan rumus tingkat keuntungan abnormal return kuadrat I pada waktu $\mathrm{t}$ dibagi dengan varian dari tingkat keuntungan diluar pengumuman. Rumus security return variability, pada penelitian Gantyowati dan Sulistiyani (2008), dapat dihitung dengan menggunakan persamaan:

$$
\mathrm{SRV}_{\mathrm{it}}=\frac{\mathrm{AR}_{\mathrm{it}}^{2}}{\mathrm{~V}\left(\mathrm{AR}_{i t}\right)}
$$

Dimana untuk mencari $\mathrm{V}\left(\mathrm{AR}_{\mathrm{it}}\right)$ dapat menggunakan rumus:

$$
\mathrm{V}\left(\mathrm{AR}_{\mathrm{it}}\right)=\frac{\left.A R_{i t}-\text { Rata }- \text { Rata } A R_{i t}\right)^{2}}{n-1}
$$

Keterangan:

$\mathrm{V}\left(\mathrm{AR}_{\mathrm{it}}\right)=$ Varian dari abnormal return pada periode di luar pengumuman.

$\mathrm{N}=$ Jumlah hari yang diamati.

\section{Analisis Data}

\section{a. Uji Normalitas}

Uji normalitas data digunakan untuk mengetahui apakah data yang digunakan dalam penelitian ini terdistribusi mormal atau tidak, karena pada dasarnya dalam melakukan penelitian data yang digunakan harus terdistribusi dengan normal. Dalam penelitian ini, uji normalitas data menggunakan uji deskriptif analisis yaiyu dengan ketentuan:

1) Jika data lebih dari 50 sampel maka menggunakan tabel statistik Kolmogrov Smirnov

$\mathrm{TVA}_{\mathrm{i}, \mathrm{t}}=\frac{\text { Ó saham } \text { i yang diperdagangkan pada hari } k e-t}{\text { Ó saham } \text { i yang beredar pada hari } k e-t}$ 
dengan ketentuan tingkat signifikasi $($ sig $)>0.05$.

2) Jika data kurang dari 50 sampel maka menggunakan tabel statistik Shapiro Wilk dengan ketentuan tingkat signifikasi $($ sig $)>0.05$.

\section{b. Uji One Sample t-Test}

One Sample t-Test adalah uji beda untuk mengetahui adakah perbedaan rata-rata pada sebuah kelompok terhadap nilai rata-rata sebuah sampel. Dalam hal ini adalah kelompok nilai rata-rata sebelum dan sesudah peristiwa yang masingmasing akan dibandingkan dengan nilai rata-rata saat peristiwa bencana banjir di wilayah Jabodetabek pada Januari 2020.

Kriteria pengujian pada ketentuan tingkat signifikansi ( sig) > 0.05 dengan melihat apakah nilai probabilitas lebih kecil atau lebih besar dari 0.05. Akan terdapat perbedaan apabila nilai probabilitas lebih besar atau sama dengan 0.05 (p $\geq 0.05$ ), dan apabila nilai probabilitas lebih kecil dari 0.05 atau (sig) $\mathrm{t}<$ 30.05 maka tidak terdapat perbedaan rerata di keduanya.

\section{HASIL PENELITIAN DAN PEMBAHASAN}

\section{a. Abnormal Return}

1) Sektor Industri Barang Konsumis

\section{Tabel 1}

Hasil Uji Normalitas Abnormal Return Sektor Industri Barang Konsumsi

\begin{tabular}{|c|l|l|l|l|}
\hline \multicolumn{2}{|c|}{ Variabel } & \multicolumn{1}{c|}{ Test } & Sig. & \multicolumn{1}{|c|}{ Keterangan } \\
\hline Rata-rata & Sebelum & One- & & Berdistribusi \\
Abnormal & & Sample & & Normal \\
Return & & Kolmogrof- & .003 & \\
Sektor & & Smirnov & & \\
Industri & & Test & & \\
Barang & Saat & One- & .023 & Berdistribusi \\
\hline
\end{tabular}

\begin{tabular}{|l|l|l|l|l|}
\hline Konsumsi & & $\begin{array}{l}\text { Sample } \\
\text { Kolmogrof- } \\
\text { Smirnov }\end{array}$ & & Normal \\
& & Test & & \\
\cline { 3 - 5 } & Sesudah & $\begin{array}{l}\text { One- } \\
\text { Sample } \\
\text { Kolmogrof- }\end{array}$ & .200 & Nordistribusi \\
& & $\begin{array}{l}\text { Smirnov } \\
\text { Test }\end{array}$ & & \\
& & & \\
\hline
\end{tabular}

Sumber: Data Diolah, 2020

Berdasarkan tabel 1 diatas dapat diketahui bahwa nilai hasil uji normalitas abnormal return pada sektor industri barang konsumsi yang ditunjukkan oleh Asymp. Sig. (2tailed) sebelum terjadinya peristiwa banjir di Jabodetabek pada Bulan Januari 2020 sebesar 0,003 , pada saat peristiwa banjir di Jabodetabek Bulan Januari 2020 sebesar 0,023, dan sesudah peristiwa banjir di Jabodetabek Bulan Januari 2020 sebesar 0,200. Sehingga dapat dikatakan data sebelum dan saat peristiwa berdistribusi normal tidak signifikan dan sesudah peristiwa data berdistribusi normal signifikan.

2) Sektor Properti, Real Estate, dan Kontruksi Bangunan

Tabel 2

Hasil Uji Normalitas Abnormal Return Sektor Properti, Real Estate, dan Kontruksi Bangunan

\begin{tabular}{|c|c|c|c|c|}
\hline \multicolumn{2}{|l|}{ Variabel } & Test & Sig. & Keterangan \\
\hline \multirow{3}{*}{$\begin{array}{l}\text { Rata-rata Abnormal } \\
\text { Return } \\
\text { Sektor Properti, Real } \\
\text { Estate, dan Kontruksi } \\
\text { Bangunan }\end{array}$} & Sebelum & $\begin{array}{l}\text { One-Sample Kolmogrof- } \\
\text { Smirnov Test }\end{array}$ & .200 & $\begin{array}{l}\text { Berdistribusi } \\
\text { Normal }\end{array}$ \\
\hline & Saat & $\begin{array}{l}\text { One-Sample Kolmogrof- } \\
\text { Smirnov Test }\end{array}$ & .008 & $\begin{array}{l}\text { Berdistribusi } \\
\text { Normal }\end{array}$ \\
\hline & Sesudah & $\begin{array}{l}\text { One-Sample Kolmogrof- } \\
\text { Smirnov Test }\end{array}$ & .050 & $\begin{array}{l}\text { Berdistribusi } \\
\text { Normal }\end{array}$ \\
\hline
\end{tabular}

Sumber: Data Diolah, 2020

Berdasarkan tabel 2 diatas dapat diketahui bahwa nilai hasil uji normalitas abnormal return pada sektor properti, real estate, dan kontruksi bangunan yang ditunjukkan oleh Asymp. Sig. (2tailed) sebelum terjadinya peristiwa 
banjir di Jabodetabek pada Bulan Januari 2020 sebesar 0,200, pada saat peristiwa banjir di Jabodetabek Bulan Januari 2020 sebesar 0,008, dan sesudah peristiwa banjir di Jabodetabek Bulan Januari 2020 sebesar 0,050. Sehingga dapat dikatakan data sebelum dan sesudah peristiwa berdistribusi normal signifikan dan saat peristiwa data berdistribusi normal tidak signifikan.

3) Sektor Infrastruktur, Utilitas, dan Transportasi

\section{Tabel 3}

Hasil Uji Normalitas Abnormal Return Sektor Infrastruktur, Utilitas, dan Transportasi

\begin{tabular}{|c|l|l|l|l|}
\hline \multicolumn{2}{|c|}{ Variabel } & \multicolumn{1}{c|}{ Test } & Sig. & \multicolumn{1}{|c|}{ Keterangan } \\
\hline Rata-rata & Sebelum & One- & & Berdistribusi \\
Abnormal & & Sample & & Normal \\
Return & & Kolmogrof & .200 & \\
Sektor & & - Smirnov & & \\
Infrastruktur & & Test & & \\
\cline { 2 - 5 } , Utilitas, & Saat & One- & & Berdistribusi \\
dan & & Sample & & Normal \\
Transportasi & & Kolmogrof & .200 & \\
& & - Smirnov & & \\
& & Test & & \\
\cline { 3 - 5 } & Sesudah & One- & & Berdistribusi \\
& & Sample & & Normal \\
& & Kolmogrof & .200 & \\
& & -Smirnov & & \\
& & Test & & \\
\hline
\end{tabular}

Sumber: Data Diolah, 2020

Berdasarkan tabel 3 diatas dapat diketahui bahwa nilai hasil uji normalitas abnormal return pada sektor infrastruktur, utilitas, dan transportasi yang ditunjukkan oleh Asymp. Sig. (2-tailed) sebelum terjadinya peristiwa banjir di Jabodetabek pada Bulan Januari 2020 sebesar 0,200, pada saat peristiwa banjir di Jabodetabek Bulan Januari 2020 sebesar 0,200, dan sesudah peristiwa banjir di Jabodetabek Bulan Januari 2020 sebesar 0,200. Sehingga dapat dikatakan data sebelum, saat, dan sesudah peristiwa berdistribusi normal signifikan.

4) Sektor Perdagangan, Jasa, dan Investasi

Tabel 4

Hasil Uji Normalitas Abnormal Return Sektor Perdagangan, Jasa, dan Investasi

\begin{tabular}{|c|l|l|l|l|}
\hline \multicolumn{2}{|c|}{ Variabel } & \multicolumn{1}{|c|}{ Test } & Sig. & \multicolumn{1}{|c|}{ Keterangan } \\
\hline Rata-rata & Sebelum & One- & & Berdistribusi \\
Abnormal & & Sample & & Normal \\
Return & & Kolmogro & .200 & \\
Sektor & & f-Smirnov & & \\
Perdagangan & & Test & & \\
\cline { 2 - 5 } , Jasa, dan & Saat & One- & & Berdistribusi \\
Investasi & & Sample & & Normal \\
& & Kolmogro & .001 & \\
& & f-Smirnov & & \\
& & Test & & \\
\cline { 3 - 5 } & Sesudah & One- & & Berdistribusi \\
& & Sample & & Normal \\
& & Kolmogro & .200 & \\
& & f-Smirnov & & \\
& & Test & & \\
\hline
\end{tabular}

Sumber: Data Diolah, 2020

Berdasarkan tabel 4 diatas dapat diketahui bahwa nilai hasil uji normalitas abnormal return pada sektor perdagngan, jasa, dan investasi yang ditunjukkan oleh Asymp. Sig. (2-tailed) sebelum terjadinya peristiwa banjir di Jabodetabek pada Bulan Januari 2020 sebesar 0,200, pada saat peristiwa banjir di Jabodetabek Bulan Januari 2020 sebesar 0,001, dan sesudah peristiwa banjir di Jabodetabek Bulan Januari 2020 sebesar 0,200. Sehingga dapat dikatakan data sebelum dan sesudah peristiwa berdistribusi normal signifikan dan saat peristiwa data berdistribusi normal tidak signifikan. 
b. Trading Volume Activity

1) Sektor Industri Barang Konsumsi

Tabel 5

Hasil Uji Normalitas Trading Volume Activity Sektor Industri Barang Konsumsi

\begin{tabular}{|c|l|l|l|l|}
\hline \multicolumn{2}{|c|}{ Variabel } & \multicolumn{1}{|c|}{ Test } & Sig. & Keterangan \\
\hline Rata-rata & Sebelum & One- & & Berdistribusi \\
Trading & & Sample & & Normal \\
Volume & & Kolmogrof- & .000 & \\
Activity & & Smirnov & & \\
Sektor & & Test & & \\
Industri & Saat & One- & & Berdistribusi \\
Barang & & Sample & & Normal \\
Konsumsi & & Kolmogrof- & .000 & \\
& & Smirnov & & \\
& & Test & & \\
\cline { 3 - 5 } & Sesudah & One- & & Berdistribusi \\
& & Sample & & Normal \\
& & Kolmogrof- & .000 & \\
& & Smirnov & & \\
& & Test & & \\
& & & & \\
& & &
\end{tabular}

Sumber: Data Diolah, 2020

Berdasarkan tabel 5 diatas dapat diketahui bahwa nilai hasil uji normalitas trading volume activity pada sektor industri barang konsumsi yang ditunjukkan oleh Asymp. Sig. (2-tailed) sebelum terjadinya peristiwa banjir di Jabodetabek pada Bulan Januari 2020 sebesar 0,000, pada saat peristiwa banjir di Jabodetabek Bulan Januari 2020 sebesar 0,000, dan sesudah peristiwa banjir di Jabodetabek Bulan Januari 2020 sebesar 0,000 . Sehingga dapat dikatakan data sebelum, saat, dan sesudah peristiwa berdistribusi normal tidak signifikan.

2) Sektor Properti, Real Estate, dan Kontruksi Bangunan

Tabel 6

Hasil Uji Normalitas Trading

Volume Activity Sektor

Properti, Real Estate, dan Kontruksi Bangunan

\begin{tabular}{|c|l|l|c|l|}
\hline \multicolumn{2}{|c|}{ Variabel } & \multicolumn{1}{|c|}{ Test } & Sig. & Keterangan \\
\hline Rata-rata & Sebelum & One- & & Berdistribusi \\
Trading & & Sample & .021 & Normal \\
Volume & & Kolmogrof- & & \\
Activity & & Smirnov & & \\
\hline
\end{tabular}

\begin{tabular}{|c|l|l|l|l|}
\hline Sektor & & Test & & \\
\cline { 2 - 5 } Properti, & Saat & One- & & Berdistribusi \\
Real & & Sample & & Normal \\
Estate, & & Kolmogrof- & .005 & \\
dan & & Smirnov & & \\
Kontruksi & & Test & & \\
Bangunan & Sesudah & $\begin{array}{l}\text { One- } \\
\text { Sample }\end{array}$ & & Berdistribusi \\
& & Kolmogrof- & .086 & Normal \\
& & Smirnov & & \\
& & & \\
& & & & \\
& & & & \\
& & & & \\
\end{tabular}

Sumber: Data Diolah, 2020

Berdasarkan tabel 6 diatas dapat diketahui bahwa nilai hasil uji normalitas traading volume activity pada sektor properti, real estate, dan kontruksi bangunan yang ditunjukkan oleh Asymp. Sig. (2tailed) sebelum terjadinya peristiwa banjir di Jabodetabek pada Bulan Januari 2020 sebesar 0,021, pada saat peristiwa banjir di Jabodetabek Bulan Januari 2020 sebesar 0,005, dan sesudah peristiwa banjir di Jabodetabek Bulan Januari 2020 sebesar 0,086. Sehingga dapat dikatakan data sebelum dan saat peristiwa berdistribusi normal tidak signifikan dan sesudah peristiwa data berdistribusi normal signifikan.

3) Sektor Infrastruktur, Utilitas, dan Transportasi

Tabel 7

Hasil Uji Normalitas Trading Volume Activity Sektor Infrastruktur, Utilitas, dan Transportasi

\begin{tabular}{|c|l|l|l|l|}
\hline \multicolumn{2}{|c|}{ Variabel } & \multicolumn{1}{|c|}{ Test } & Sig. & \multicolumn{1}{|c|}{ Keterangan } \\
\hline Rata-rata & Sebelum & One- & & Berdistribusi \\
Trading & & Sample & & Normal \\
Volume & & Kolmogro & .200 & \\
Activity & & f-Smirnov & & \\
Sektor & & Test & & \\
\cline { 2 - 5 } Infrastruktur & Saat & One- & & Berdistribusi \\
, Utilitas, & & Sample & & Normal \\
dan & & Kolmogro & .200 & \\
Transportasi & & f-Smirnov & & \\
& & Test & & \\
\cline { 3 - 5 } & Sesudah & One- & & Berdistribusi \\
& & Sample & & Normal \\
& & Kolmogro & .200 & \\
& & f-Smirnov & & \\
& & Test & & \\
& & & &
\end{tabular}

Sumber: Data Diolah, 2020 
Berdasarkan tabel 7 diatas dapat diketahui bahwa nilai hasil uji normalitas trading volume activity pada sektor infrastruktur, utilitas, dan transportasi yang ditunjukkan oleh Asymp. Sig. (2-tailed) sebelum terjadinya peristiwa banjir di Jabodetabek pada Bulan Januari 2020 sebesar 0,200, pada saat peristiwa banjir di Jabodetabek Bulan Januari 2020 sebesar 0,200, dan sesudah peristiwa banjir di Jabodetabek Bulan Januari 2020 sebesar 0,200. Sehingga dapat dikatakan data sebelum, saat, dan sesudah peristiwa berdistribusi normal signifikan.

4) Sektor Perdagangan, Jasa, dan Investasi

Tabel 8

Hasil Uji Normalitas Trading Volume Activity Sektor Perdagangan, Jasa, dan Investasi

\begin{tabular}{|c|c|c|c|c|}
\hline \multicolumn{2}{|c|}{ Variabel } & Test & Sig. & Keterangan \\
\hline \multirow{3}{*}{$\begin{array}{c}\text { Rata-rata } \\
\text { Trading } \\
\text { Volume } \\
\text { Activity } \\
\text { Sektor } \\
\text { Perdagangan } \\
\text {, Jasa, dan } \\
\text { Investasi }\end{array}$} & $\begin{array}{l}\text { Sebelu } \\
\mathrm{m}\end{array}$ & $\begin{array}{l}\text { One- } \\
\text { Sample } \\
\text { Kolmogrof } \\
\text {-Smirnov } \\
\text { Test } \\
\end{array}$ & $\begin{array}{c}.00 \\
6\end{array}$ & $\begin{array}{l}\text { Berdistribus } \\
\text { i Normal }\end{array}$ \\
\hline & Saat & $\begin{array}{l}\text { One- } \\
\text { Sample } \\
\text { Kolmogrof } \\
\text {-Smirnov } \\
\text { Test }\end{array}$ & $\begin{array}{c}.00 \\
1\end{array}$ & $\begin{array}{l}\text { Berdistribus } \\
\text { i Normal }\end{array}$ \\
\hline & Sesudah & $\begin{array}{l}\text { One- } \\
\text { Sample } \\
\text { Kolmogrof } \\
\text {-Smirnov } \\
\text { Test } \\
\end{array}$ & $\begin{array}{c}.20 \\
0\end{array}$ & $\begin{array}{l}\text { Berdistribus } \\
\text { i Normal }\end{array}$ \\
\hline
\end{tabular}

Sumber: Data Diolah, 2020

Berdasarkan tabel 8 diatas dapat diketahui bahwa nilai hasil uji normalitas trading volume activity pada sektor perdagngan, jasa, dan investasi yang ditunjukkan oleh Asymp. Sig. (2-tailed) sebelum terjadinya peristiwa banjir di Jabodetabek pada Bulan Januari 2020 sebesar 0,006, pada saat peristiwa banjir di Jabodetabek
Bulan Januari 2020 sebesar 0,001, dan sesudah peristiwa banjir di Jabodetabek Bulan Januari 2020 sebesar 0,200. Sehingga dapat dikatakan data sebelum dan saat peristiwa berdistribusi normal tidak signifikan dan sesudah peristiwa data berdistribusi normal signifikan.

\section{c. Security Return Variability}

1) Sektor Industri Barang Konsumsi

Tabel 9

\section{Hasil Uji Normalitas Security Return Variability Sektor Industri Barang Konsumsi}

\begin{tabular}{|c|l|l|l|l|}
\hline \multicolumn{2}{|c|}{ Variabel } & \multicolumn{1}{c|}{ Test } & Sig. & Keterangan \\
\hline Rata-rata & Sebelum & One- & & Berdistribusi \\
Security & & Sample & & Normal \\
Return & & Kolmogrof- & .001 & \\
Variability & & Smirnov & & \\
Sektor & & Test & & \\
\cline { 2 - 5 } Industri & Saat & One- & & Berdistribusi \\
Barang & & Sample & & Normal \\
Konsumsi & & Kolmogrof- & .000 & \\
& & Smirnov & & \\
& & Test & & \\
\cline { 3 - 5 } & Sesudah & One- & & Berdistribusi \\
& & Sample & & Normal \\
& & Kolmogrof- & .000 & \\
& & Smirnov & & \\
& & Test & & \\
& & & & \\
& & &
\end{tabular}

Sumber: Data Diolah, 2020

Berdasarkan tabel 9 diatas dapat diketahui bahwa nilai hasil uji normalitas security return variability pada sektor industri barang konsumsi yang ditunjukkan oleh Asymp. Sig. (2-tailed) sebelum terjadinya peristiwa banjir di Jabodetabek pada Bulan Januari 2020 sebesar 0,001, pada saat peristiwa banjir di Jabodetabek Bulan Januari 2020 sebesar 0,020, dan sesudah peristiwa banjir di Jabodetabek Bulan Januari 2020 sebesar 0,000. Sehingga dapat dikatakan data sebelum, saat, dan sesudah peristiwa berdistribusi normal tidak signifikan. 
2) Sektor Properti, Real Estate, dan Kontruksi Bangunan

Tabel 10

\section{Hasil Uji Normalitas Security Return Variability Sektor Properti, Real Estate dan Kontruksi Bangunan}

\begin{tabular}{|c|l|l|l|l|}
\hline \multicolumn{2}{|c|}{ Variabel } & \multicolumn{1}{c|}{ Test } & Sig. & Keterangan \\
\hline Rata-rata & Sebelum & One- & & Berdistribusi \\
Security & & Sample & & Normal \\
Return & & Kolmogrof- & .000 & \\
Variability & & Smirnov & & \\
Sektor & & Test & & \\
Properti, & Saat & One- & & Berdistribusi \\
Real & & Sample & & Normal \\
Estate, & & Kolmogrof- & .000 & \\
dan & & Smirnov & & \\
Kontruksi & & Test & & \\
Bangunan & Sesudah & One- & & Berdistribusi \\
& & Sample & & Normal \\
& & Kolmogrof- & .000 & \\
& & Smirnov & & \\
& & Test & & \\
& & &
\end{tabular}

Sumber: Data Diolah, 2020

Berdasarkan tabel 10 diatas dapat diketahui bahwa nilai hasil uji normalitas security return variability pada sektor properti, real estate, dan kontruksi bangunan yang ditunjukkan oleh Asymp. Sig. (2tailed) sebelum terjadinya peristiwa banjir di Jabodetabek pada Bulan Januari 2020 sebesar 0,001, pada saat peristiwa banjir di Jabodetabek Bulan Januari 2020 sebesar 0,020, dan sesudah peristiwa banjir di Jabodetabek Bulan Januari 2020 sebesar 0,000. Sehingga dapat dikatakan data sebelum, saat, dan sesudah peristiwa berdistribusi normal tidak signifikan.
3) Sektor Infrastruktur, Utilitas, dan Transportasi

Tabel 11

Hasil Uji Normalitas Security Return Variability Sektor Infrastruktur, Utilitas, dan Transportasi

\begin{tabular}{|c|l|l|l|l|}
\hline \multicolumn{2}{|c|}{ Variabel } & \multicolumn{1}{c|}{ Test } & Sig. & Keterangan \\
\hline Rata-rata & Sebelum & One- & & Berdistribusi \\
Security & & Sample & & Normal \\
Return & & Kolmogrof- & .006 & \\
Variability & & Smirnov & & \\
Sektor & & Test & & \\
\cline { 2 - 5 } Infrastruktur, & Saat & One- & & Berdistribusi \\
Utilitas, dan & & Sample & & Normal \\
Transportasi & & Kolmogrof- & .000 & \\
& & Smirnov & & \\
& & Test & & \\
\cline { 3 - 5 } & Sesudah & One- & & Berdistribusi \\
& & Sample & & Normal \\
& & Kolmogrof- & .038 & \\
& & Smirnov & & \\
& & Test & & \\
& & &
\end{tabular}

Sumber: Data Diolah, 2020

Berdasarkan tabel 11 diatas dapat diketahui bahwa nilai hasil uji normalitas security return variability pada sektor infrastruktur, utilitas, dan transportasi yang ditunjukkan oleh Asymp. Sig. (2-tailed) sebelum terjadinya peristiwa banjir di Jabodetabek pada Bulan Januari 2020 sebesar 0,006, pada saat peristiwa banjir di Jabodetabek Bulan Januari 2020 sebesar 0,000 , dan sesudah peristiwa banjir di Jabodetabek Bulan Januari 2020 sebesar 0,038. Sehingga dapat dikatakan data sebelum, saat, dan sesudah peristiwa berdistribusi normal tidak signifikan. 
4) Sektor Perdagangan, Jasa, dan Investasi

Tabel 12

Hasil Uji Normalitas Security Return Variability Sektor Perdagangan, Jasa, dan Investasi

\begin{tabular}{|c|l|l|l|l|}
\hline \multicolumn{2}{|c|}{ Variabel } & \multicolumn{1}{c|}{ Test } & Sig. & Keterangan \\
\hline Rata-rata & Sebelum & One- & & Berdistribusi \\
Security & & Sample & & Normal \\
Return & & Kolmogrof- & .021 & \\
Variability & & Smirnov & & \\
Sektor & & Test & & \\
Perdagangan, & Saat & One- & & Berdistribusi \\
Jasa, dan & & Sample & & Normal \\
Investasi & & Kolmogrof- & .002 & \\
& & Smirnov & & \\
& & Test & & \\
\cline { 3 - 5 } & Sesudah & One- & & Berdistribusi \\
& & Sample & & Normal \\
& & Kolmogrof- & .000 & \\
& & Smirnov & & \\
& & Test & & \\
& & & & \\
& & &
\end{tabular}

Sumber: Data Diolah, 2020

Berdasarkan tabel 12 diatas dapat diketahui bahwa nilai hasil uji normalitas security return variability pada sektor perdagangan, jasa, dan investasi yang ditunjukkan oleh Asymp. Sig. (2-tailed) sebelum terjadinya peristiwa banjir di Jabodetabek pada Bulan Januari 2020 sebesar 0,021, pada saat peristiwa banjir di Jabodetabek Bulan Januari 2020 sebesar 0,002, dan sesudah peristiwa banjir di Jabodetabek Bulan Januari 2020 sebesar 0,000. Sehingga dapat dikatakan data sebelum, saat, dan sesudah peristiwa berdistribusi normal tidak signifikan.

\section{KESIMPULAN}

Berdasarkan hasil penelitian Peristiwa Bencana Banjir di Jakarta, Bogor, Depok, Tangerang, dan Bekasi (Jabodetabek) pada Bulan Januari 2020 mendapat beberapa kesimpulan sebagai berikut:

a. Berdasarkan hasil penelitian dilihat dari Abnormal Return peristiwa bencana banjir di
Jabodetabek pada Bulan Januari 2020 pada kelompok sektor industri barang konsumsi, sektor infrastruktur utilitas dan transportasi, dan sektor perdagangan jasa dan investasi tidak memberikan perubahan yang signifikan sebelum dan sesudah peristiwa, hanya memberikan perubahan yang signifikan pada saat peristiwa. Pada sektor properti, real estate, dan kontruksi bangunan memberikan dampak perubahan yang signifikan pada saat peristiwa dimana nilai sig. sebesar 0,000 dan sesudah peristiwa nilai sig. sebesar 0,018 , hanya saja tidak memberikan prubahan pada sebelum peristiwa terjadi yang mana dampak tersebut bersifat sementara dan tidak berkepanjangan.

b. Berdasarkan hasil penelitian dilihat dari Trading Volume Activity peristiwa bencana banjir di Jabodetabek pada Bulan Januari 2020 pada kelompok sektor properti real estate dan kontruksi dan bangunan, sektor infrastruktur utilitas dan transportasi, dan sektor perdagangan jasa dan investasi memberikan perubahan yang signifikan sebelum, saat dan sesudah peristiwa. Nilai sig. Pada kemompok sektor properti real estate dan kontruksi bangunan sebelum, saat dan sesudah peristiwa sebesar 0,000 , nilai sig. pada kelompok sektor infrastruktur utilitas dan transportasi pada sebelum peristiwa sebesar 0,21, pada saat peristiwa sebesar 0,010, dan sesudah peristiwa sebesar 0,012 . Pada kelompok sektor 
perdagangan jasa dan infrastruktur nilai sig. pada saat terjadinya peristiwa sebesar 0,011 , pada saat peristiwa sebesar 0,016 dan sesudah peristiwa sebesar 0,002. Pada sektor indutri barang konsumsi tidak memberikan perubahan yang signifikan pada sebelum dan sesudah peristiwa, dimana hanya berdampak pada saat terjadinya peristiwa.

c. Berdasarkan hasil penelitian dilihat dari Security Return Variability peristiwa bencana banjir di Jabodetabek pada Bulan Januari 2020 pada kelompok sektor industri barang konsumsi dan infrastruktur, utilitas dan transportasi tidak memberikan perubahan yang signifikan sebelum, saat dan sesudah peristiwa. Pada sektor perdagangan, jasa, dan investasi memberikan dampak perubahan yang signifikan pada sebelum dimana nilai sig. sesbesar 0,025 dan saat peristiwa nilai sig. sebesar 0,000, hanya saja tidak memberikan prubahan pada sesudah peristiwa terjadi yang mana dampak tersebut bersifat sementara dan tidak berkepanjangan. Pada sektor properti, real estate, dan kontruksi bangunan tidak memberikan perubahan yang signifikan pada sebelum dan sesudah peristiwa, dimana hanya berdampak pada saat terjadinya peristiwa dengan nilai sig. 0,000 .

\section{DAFTAR PUSTAKA}

Al-Quran Kariim

Al- Hadits

Arikonto, Suharsimi. 2010. Prosedur Penelitian Pendekatan Suatu Praktek. Jakarta: Rineka Cipta.

Bringham, F. Eugene dan Houston, Joel. 2010. Dasar-Dasar Manajemen Keuangan: Assentials of Financial Management. Jakarta: Salemba Empat.

Darmadji, Tjiptono dan Hendy, M. Fakhrudin. 2012. Pasar Modal Di Indonesia Edisi Ketiga. Jakarta: Salemba Empat.

Empirical Work. Journal of Finance 25. Pp387-417.

Fahmi, Irham. 2012. Pengantar Pasar Modal. Bandung: Alfabeta.

Fama, Eugene F. 1970. Efficient Capital Market : A Review of Theory and

Fanni, Christian Martha. 2013. Reaksi Pasar Modal Terhadap Bencana Banjir Jakarta Tahun 2013 (Event Study Pada Saham Perusahaan Asuransi Yang Listing Di BEI). Malang: Universitas Brawijaya.

Feranita, Nungky Viana. 2014. Reaksi Pasar Modal Indonesia Terhadap Peristiwa Bencana Alam Tsunami Di Aaceh Tanggal 26 Desember 2004. Majalah Ilmiah Dian Ilmu: Vol. 13 (No. 2)

Foster, G. 1986. Financiall Statement Analysis, Second Edition Englewood Cliffs 
New Jerssey: Printice Hall International.

Halim, Abdul. 2005. Analisis Investasi. Jakarta: Selemba Empat

Hartono, Jogiyanto. 2008. Teori Portofolio dan Analisis Investasi Edisi

Keenam.Yogyakarta: BPFE.

Hartono, Jogiyanto. 2010. Teori Portofolio dan Analisis Investasi Edisi Ketujuh. Yogyakarta: BPFE.

Hartono, Jogiyanto. 2013. Teori Portofolio dan Analisis Investasi Edisi Kedelapan. Yogyakarta: BPFE.

Husnan, Suad. 1996. Dasar-dasar Teori Portofolio Dan Analisis Sekuritas. Yogyakarta: UPP AMP YKPN.

Kahf, Monzer. 1995. Ekonomi Islam (Telaah Analitik Terhadap Fungsi Sistem Ekonomi Islam). Yogyakarta: Pustaka Pelajar.

Parmadi, N.K.A.R., Adiputra, I.M.P., \& Dharmawan, N.A.S. 2014. Analisis Reaksi Investor Terhadap Kenaikan Harga Bahan Bakar Minyak di Bursa Efek Indonesia (Event Study terhadap Kenaikan Harga BBM pada 21 Juni 2013 di Indonesia). E-Journal S1 Ak Universitas Pendidikan Ganesha, Vol:2, No:1.

Rofiki, David, Topowijono, dan Nurlaily, Ferina. 2018. Reaksi Pasar Modal Indonesia Akibat Peristiwa Pemilihan Gubernur DKI Jakarta Putaran II 2017 (Event Study Pada Saham Perusahaan Yang Terdaftar Di Indeks $L Q$ 45 Periode Febuari - Juli
2017). Jurnal Administrasi Bisnis (JAB): Vol. 62 (No. 2)

Romansyah. 2015. Pasar Modal Dalam Perspektif Islam. Mazahib: Vol XIV (No. 1).

Rusli, Muhammad. 2014. Pengelolaan Statistik Yang Menyenangkan. Yogyakarta: Graha Ilmu.

Samsul, Mohamad. 2006. Pasar Modal dan Manajemen Portofolio. Surabaya: Erlangga

Sari, Eka Sriwulan, Afifudin dan Junaidi. 2018. Reaksi Investor Dalam Pasar Modal Terhadap Perppu Ormas (Peraturan Pemerintah Pengganti Undang-Undang Organisasi Masyarakat) No 2 Tahun 2017 (Event Study Pada Perusahaan yang Terdaftar Dalam LQ45 di Bursa Efek Indonesia). EJRA: Vol. 07 (No. 3)

Satria, Gde Agung. Artini, Luh Gede Sri. dan Rahyuda, Henny. 2017. Reaksi Pasar Terhadap China's Black Monday Di Bursa Efek Indonesia. EJurnal Ekonomi dan Bisnis Universitas Udayana: 6.7 (ISSN: 2337-3067)

Shihab, M. Quraish. 2002. Tafsir AlMisbah, Jilid 2. Jakarta: Lentera Hati

Sugiyono. 2011. Metode Penelitian Kuantitatif, Kualitatif, dan $R \& D$. Bandung: Alfabeta.

Sugiyono. 2015. Metode Penelitian Pendidikan (Pendekatan Kuantitatif, Kualitatif dan $R \& D)$. Bandung: Alfabeta.

Sumantoro.1990. Pengantar Tentang Pasar Modal di Indonesia. Jakarta: Ghalia Indonesia. 
Sunariyah. 2000. Pengantar Pengetahuan Pasar Modal. Yogyakarta: UPP AMP YKPN.

Sunariyah. 2011. Pengantar Pengetahuan Pasar Modal Edisi Keempat. Yogyakarta: UPP AMP YKPN.

Tandelilin, Eduarus. 2010. Portofolio dan Investasi Teori dan Aplikasi Edisi Pertama. Yogyakarta: Kanisius.

Wardhani, Laksmi Swastika. 2012. Reaksi pasar Modal Terhadap Peristiwa Pemilihan Gubernur DKI Jakarta Putaran II 2012 (Event Study Pada saham Anggota Indeks 100). Jurnal Ilmiah Mahasiswa FEB: Vol. 1 (No. 1).

Wibowo, Agung. 2017. Reaksi Investor Pasar Modal Indonesia Terhadap Paket Kebijakan Ekonomi tahap I Jokowi-JK (Studi Kasus Pada Saham LQ45 Periode Agustus 2015-Pebuari 2016). Media Ekonomi Manajemen: Vol. 32 (No. 1).

Widoatmodjo. 2011. Pasar Modal Indonesia. Bogor: Ghalia Indonesia.

Wintako, Laurentius Tedi. 2008. Reaksi Pasar Modal Atas Peristiwa Banjir Besar Jakarta 5 Februari 2007 dan
Dampaknya Terhadap Return Saham Pada Bursa Efek Indonesia - Studi Tentang Abnormal Return SahamSaham LQ45 Dengan Metode Market Model. Skripsi Pascasarjana Universitas Diponegoro.

Wulandari, Febby dan Khairunnisa. 2015. Reaksi Pasar Modal Terhadap Peristiwa Bencana Banjir Di Daerah Khusus Ibukota (DKI) Jakarta Tahun 2007 Dan 2013 "(Studi Kasus Pada Perusahaan Asuransi Di Bursa Efek Indonesia)". e-Proceeding of Management : Vol.2 (No. 1)

Yuwono, Andri. (2013). Reaksi Pasar Modal di Bursa Efek Indonesia terhadap Pengumuman Peristiwa Bencana Banjir yang Melanda Daerah Khusus Ibukota Jakarta Tahun 2013 . Jurnal Nominal Fakultas Ekonomi Universitas Negeri Yogyakarta, Vol.2, No.2. Hal. 135-150.

bisnis.com

finance.detik.com

kompas.com

tafsirq.com

tribunjateng.com

www.idx.co.id

yahoo.finance.com 